\title{
Perencanaan Keuangan Islam Sederhana dalam Bisnis E-Commerce pada Pengguna Online Shop
}

\author{
Naili Saadah \\ Universitas Islam Negeri Walisongo Semarang \\ email: naili_saadah@walisongo.ac.id
}

\begin{abstract}
Technological developments and digitalization in all sectors including the industrial sector force all industry players to follow if they want to survive. Behind the digitalization that targets all aspects of transactions, as a Muslim, there are basic rules that muststill be used as guidelines, including not forgetting the aspects of sharia in dealing with it especially in the current era of globalization. This study will examine how e-commerce business as part of the industrial revolution synergizes with Islam which is implemented in the form of simple Islamic financial planning. Using ethnography studies and adjoining case study methods this study investigates two participants as micro-entrepreneurs who implement e-commerce. The results of the study prove that microentrepreneurs in the e-commerce business have implemented Islamic financial planning in a simple way through the allocation of specific budgets for worship needs such as zakat, infaq and alms in their financial planning.
\end{abstract}

Keywords: Islamic Financial Planning; Micro Business; E-Commerce.

\begin{abstract}
Abstrak: Perkembangan teknologi dan digitalisasi di semua sektor memaksa semua pelaku industri untuk mengikutinya jika ingin tetap bertahan. Di balik digitalisasi yang menyasar semua aspek transaksi, sebagai seorang muslim ada aturan dasar yang tetap harus dijadikan pedoman, di antaranya tidak melupakan aspek syariah dalam bermuamalah apalagi di era globalisasi saat ini. Penelitian ini akan mengkaji bagaimana bisnis e-commerce sebagai bagian dari revolusi industri bersinergi dengan Islam yang diimplementasikan dalam bentuk perencanaan keuangan Islam secara sederhana. Menggunakan studi etnograpi dan metode studi kasus yang berdampingan penelitian ini mengobsevasi dua partisipan sebagai pelaku usaha mikro yang menerapkan $e$ commerce. Hasil penelitian membuktikan bahwa pelaku usaha mikro dalam bisnis e-commerce telah menerapkan perencanaan keuangan Islam secara sederhana melalui pengalokasian anggaran khusus untuk kebutuhan ibadah, seperti zakat, infak dan sedekah dalam perencanaan keuangannya.
\end{abstract}

Kata Kunci: Perencanaan Keuangan Islam; Usaha Mikro; E-Commerce.

Economica: Jurnal Ekonomi Islam - Volume 9, Nomor 1 (2018) 
Naili Saadah

\section{Pendahuluan}

Perkembangan teknologi menjadikan dunia saat ini seakan tidak bersekat, jarak yang jauh seakan lenyap dengan kemudahan yang ditawarkan teknologi internet. Perkembangan teknologi yang pesat menjadi latar belakang terjadinya revolusi industri 4.0. Suka ataupun tidak, tidak ada pilihan lain bagi pelaku industri selain mengikutinya. Perubahan yang terjadi saat ini memaksa pelaku usaha untuk mengikuti trend. Digitalisasi di semua sektor termasuk sektor industri harus dilakukan jika ingin tetap bertahan di tengah era global. Teknologi internet sebagai bagian dari revolusi industri 4.0 hadir bagaikan pedang bermata dua; di satu sisi memberikan peluang yang menjanjikan namun di sisi lain mengancam keberlangsungan beberapa industri. Perkembangan dunia internet yang merambah sektor perekonomian melahirkan sebuah teknologi keuangan atau yang lebih dikenal dengan istilah financial technology (fintech). Sebenarnya fintech bukan merupakan hal yang baru karena seorang ahli bernama profesor Arner et al. (Arner, Barberis, and Buckley 2017) telah membagi perkembangan fintech menjadi empat fase.

Rentang waktu mulai dari 1866-1967 merupakan fase awal lahirnya fintech di mana pada saat itu terjadi pembentukan jaringan keuangan global melalui pengembangan infrastruktur dan komputerisasi. Kemudian dilanjutkan dengan penggunaan internet dan digitalisasi di sektor keuangan yang terjadi pada tahun 1967-2008 sebagai fase kedua. Kehadiran smartphone sebagai bentuk perkembangan fintech fase ketiga dimulai tahun 2008 hingga saat ini yang telah mencapai perkembangan fintech fase keempat yang ditandai dengan kemunculan teknologi bisnis keuangan yang mampu merubah perilaku atau kebiasaan masyarakat dalam bertransaksi (Arner, Barberis, and Buckley 2017). Semua aktivitas manusia dapat dimudahkan dengan adanya teknologi internet tidak terkecuali dengan aktivitas ekonomi. Pada era digital saat ini perilaku manusia dalam mengakses informasi dan layanan elektronik sangat dipengaruhi oleh teknologi. Semua informasi dan kebutuhan manusia bisa dipenuhi hanya lewat genggaman tangan melalui 
smartphone. Perkembangan teknologi yang semakin maju menjadikan sektor ekonomi berkembang ke arah yang lebih efisien dan modern sehingga menjadi lebih efektif.

Dampak perkembangan teknologi merambah hingga ke Indonesia. Hal ini ditandai dengan semakin menjamurnya bisnis e-commerce sebagai bagian dari financial technology. Oleh sebab itu perkembangan teknologi keuangan menjadi kajian penting saat ini. Apalagi perkembangan teknologi internet menjadikan semua belahan dunia dapat mengakses informasi dengan bebas yang berdampak pada transfer budaya dan ideologi yang tidak terbendung seakan tidak bersekat. Terlebih pemaparan sebelumnya menjelaskan bahwa perkembangan financial technology pada fase keempat juga ditandai dengan perubahan perilaku dalam berbisnis. Sebagai manusia yang hidup pada era globalisasi dipaksa untuk terus berinovasi agar mampu bertahan hidup. Bukan tidak mungkin berdampak pada perilaku negatif dalam berbisnis. Oleh karena itu agama sebagai panduan berperilaku menjadi fondasi dasar untuk menepis dampak negatif dari perkembangan teknologi.

Islam sebagai agama universal yang tidak lekang oleh zaman untuk mengatur akidah, syariah dan akhlak secara komprehensif, hadir menjadi pedoman bagi setiap muslim untuk melakukan kegiatan transaksi bisnis $e$ commerce. Karena salah satu aspek penting terkait hubungan antar manusia adalah ekonomi (Arwani 2012). Ekonomi menjadi dasar untuk mencukupi kebutuhan dan kesejahteraan seseorang. Jika dalam ekonomi konvensional kesejahteraan diartikan sebagai tercukupinya kebutuhan untuk mencapai kepuasan pribadi maka ekonomi Islam memandang kesejahteraan dengan perspektif yang lebih luas. Kesejahteraan sosial dalam ekonomi Islam berawal dari konsep pemikiran sosio ekonomi yang digagas oleh Al-Ghazali. Imam AlGhazali dalam bukunya, Ihyō 'Ulūm al-Dīn, mengungkapkan bahwa kesejahteraan masyarakat akan terwujud ketika terpenuhinya lima tujuan dasar manusia, yakni agama, jiwa, akal, harta dan keturunan.

Economica: Jurnal Ekonomi Islam - Volume 9, Nomor 1 (2018) 
Naili Saadah

Sejalan dengan pemikiran Al-Ghazali, Chapra (Chapra 2001) mendeskripsikan kesejahteraan sebagai tujuan manusia untuk mendapatkan kebahagiaan di dunia dan akhirat (faläh). Dengan demikian maka benar pendapat yang dikemukakan Masruroh (Masruroh 2013) bahwa kesejahteraan diartikan sebagai kesuksesan hidup di dunia dalam menjalankan fungsinya sebagai khalifah untuk beribadah kepada Allah. Karena pada prinsipnya manusia diciptakan untuk beribadah kepada Allah sebagaimana firman Allah dalam Al-Qur'an :

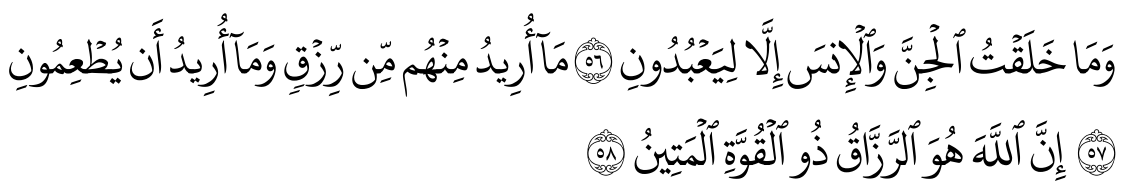

"Dan aku tidak menciptakan jin dan manusia melainkan supaya mereka mengabdi kepada-Ku* Aku tidak menghendaki rezeki sedikit pun dari mereka dan Aku tidak menghendaki supaya mereka memberi-Ku makan * Sesungguhnya Allah Dialah Maha Pemberi rezeki Yang mempunyai Kekuatan lagi Sangat Kokoh." (QS. al-Dzariyat [51]: 56-58)

Ayat tersebut menegaskan bahwa tidak hanya kepuasan pribadi yang harus kita penuhi akan tetapi ada kewajiban ibadah yang harus kita penuhi, di antaranya memenuhi hak orang lain dari rezeki yang kita terima. Keseimbangan pemenuhan kebutuhan pribadi dan pemenuhan hak orang lain sebagai wujud ibadah mewajibkan kita untuk dapat mengelola uang dengan baik. Untuk itu dibutuhkan perencanaan keuangan yang matang.

Masruroh (Masruroh 2013) mengenalkan konsep good money habit atau kebiasaan yang baik dalam membelanjakan uang di mana konsep ini sangat dipengaruhi oleh perilaku seseorang dalam mengambil keputusan finansialnya. Jika Masruroh mengenalkan konsep good money habbit, maka penelitian Fidiana (Fidiana 2014) mengelaborasi kesadaran akan zakat dan pajak dalam merencanakan keuangan pribadi, di mana hasil penelitiannya membuktikan bahwa menganggarkan pengeluaran untuk zakat ternyata lebih besar daripada pajak. Kesadaran akan good money habbit dalam 
perencanaan keuangan Islam telah diimplementasikan dalam bentuk penganggaran zakat yang lebih tinggi.

Fakta tersebut menarik peneliti untuk mengetahui konsep good money habbit yang diimplementasikan dalam kondisi yang berbeda. Jika penelitian Fidiana (Fidiana 2014) menggunakan partisipan seorang pemuka agama atau ustaz yang berprofesi sebagai guru dan pengusaha, maka penelitian ini mengelaborasi kesadaran akan konsep Islam dalam perencanaan keuangan seseorang yang awam akan hukum Islam. Mengelaborasi lebih lanjut mengenai konsep good money habbit dalam perencanaan keuangan Islam yang dipahami oleh seorang wirausaha muslim di sektor e commerce menjadi daya tarik karena saat ini bisnis sektor mikro yang menggunakan marketplace baik berbayar ataupun tidak mulai menjamur sehingga penting untuk mengetahui lebih dalam akan kesadaran penerapan good money habbit bagi pelaku usaha e-commerce.

\section{Landasan Teori}

\section{Financial Technology sebagai Bagian dari Revolusi Industri 4.0}

Tidak dapat dipungkiri bahwa teknologi telah mempermudah aktivitas manusia, tidak terkecuali aktivitas dalam pembayarab (payment). Jika dulu masyarakat masih belum mampu menggabungkan teknologi dengan keuangan untuk aktivitas sehari-hari, berbeda dengan saat ini. Era digital memaksa semua orang untuk ikut update dengan perkembangan teknologi terutama teknologi internet. Generasi millenial saat ini sangat sensitif dengan perkembangan teknologi internet sehingga membuat beberapa orang kreatif berlomba-lomba untuk memproduksi atau membuat aplikasi pembayaran online yang mampu mempermudah aktivitas masyarakat. Menurut hasil survey yang telah dilakukan oleh Asosiasi Jaringan Penyelenggara Internet Indonesia (APJII) yang dipublikasikan oleh mastel.id menunjukkan bahwa pengguna internet Indonesia mencapai 143,26 juta jiwa dari total populasi 
Naili Saadah

penduduk sebesar 262 juta orang ("Tahun 2017 Jumlah Pengguna Internet Di Indonesia Capai 143.26 Juta | Mastel.Id" n.d.).

Pesatnya pertumbuhan pengguna internet di indonesia berbanding lurus dengan perkembangan fintech. Financial technology mampu merubah sektor bisnis di Indonesia sehingga memaksa pelaku usaha untuk berkolaborasi dengan perusahan-perusahaan fintech untuk mempermudah layanan. Mengutip pernyataan Arner et al. (Arner, Barberis, and Buckley 2017), financial technology merujuk pada teknologi yang memungkinkan untuk mengatasi solusi keuangan. Selanjutnya Arner et al. menyebutkan bahwa istilah fintech tidak hanya terbatas pada sektor tertentu misalnya pembiayaan atau peer to peer landing (P2P) tetapi semua aspek jasa industri keuangan yang sebelumnya menggunakan cara tradisional. Sehingga dapat disimpulkan bahwa fintech merupakan inovasi yang merubah cara bertransaksi, yang semula tradisional bertransformasi ke arah digital dengan media internet.

Mengutip pernyataan McAuley (McAuley n.d.), financial technology dideskripsikan secara sederhana yaitu industri ekonomi yang terdiri dari perusahaan yang menggunakan teknologi untuk membuat sistem keuangan menjadi lebih efisien. Berdasarkan pernyataan tersebut jelas bahwa financial technology merupakan sebuah inovasi di bidang industri keuangan yang mampu menjadikan sektor jasa keuangan menjangkau nasabah atau konsumen lebih luas sehingga menjadi efektif dan efisien. Fintech merupakan penggabungan atau kolaborasi antara teknologi dan finansial dimana teknologi dapat berupa otomatisasi layanan dengan mesin atau penggunaan media internet untuk mempermudah layanan, namun saat ini media internet menjadi pilihan yang utama bagi pelaku industri sektor keuangan. Hal ini didasarkan pada hasil survey dari fintech Indonesia yang dipublikasikan pada website daily social.id yang menyatakan bahwa terdapat lima area fintech yang memiliki kebutuhan paling tinggi dalam pengembangan regulasi, yaitu payment gateway (60\%), e-money atau e-wallet (58\%), mekanisme know your client (KYC) (57\%), dan digital signature (54\%) ("Survei Fintech Indonesia 
Perencanaan Keuangan Islam Sederhana...

2016: 61 Persen Startup Fintech Anggap Regulasi Di Indonesia Belum Jelas | Dailysocial" n.d.)

\section{E-Commerce sebagai Bagian dari Fintech}

Salah satu area fintech yang paling besar pangsa pasarnya adalah payment gateway di mana e-commerce termasuk di dalamnya. Sebagaimana hasil survey yang telah dipaparkan sebelumnya bahwa pengguna payment gateway mencapai $60 \%$ atau paling tinggi dibandingkan area fintech yang lain. Melihat fakta tersebut menjadi semakin mudah bagi pemerintah untuk mewujudkan cashless society. Pencanangan program Gerakan Nasional Non Tunai (GNNT) yang bertujuan untuk mewujudkan masyarakat yang bertransaksi nontunai (cashless society) menjadikan digital payment dalam bisnis e-commerce menjadi alternatif utama pilihan bertransaksi. Apalagi jika melihat potensi masyarakat Indonesia yang begitu besar dalam kecenderungan untuk bertransaksi online saat ini.

Laudon dalam Maulana et al. (Maulana, Susilo, and Riyadi 2015) mendefiniskan electronic commerce atau e-commerce sebagai penggunaan internet untuk aktivitas transaksi bisnis dengan konsumen yang meliputi World Wide Web untuk penjualan produk dan pelayanan konsumen. Laudon dalam Maulana et al. (Maulana, Susilo, and Riyadi 2015) menggolongkan $e$ commerce menjadi lima, yaitu Business to Consumer (B2C), Business to Business (B2B), Consumer to Consumer (C2C), Peer to Peer (P2P), dan MobileCommerce (M-Commerce)

Penggolongan lima area e-commerce tersebut bukan tanpa sebab karena masing-masing memiliki karakteristik yang berbeda. Sebagai contoh untuk $e$ commerce yang paling besar pangsa pasarnya adalah Bussiness to Consumer (B2C). B2C banyak diminati karena meliputi transaksi yang paling sering digunakan oleh masyarakat yaitu penjualan, pembelian dan penawaran baik itu melalui marketplace ataupun media sosial. Disadari atau tidak, kustomisasi

Economica: Jurnal Ekonomi Islam - Volume 9, Nomor 1 (2018) http://journal.walisongo.ac.id/index.php/economica 
Naili Saadah

massal telah merubah pola masyarakat dalam bertransaski. Hal ini sebagai akibat dari perkembangan financial technology saat ini.

Sejalan dengan mulai terjadinya revolusi industri 4.0, e-commerce menjadi suatu kebutuhan primer bagi pelaku industri untuk memenangkan persaingan. Hal ini tidak lain karena berbagai kemudahan dan keefektifan yang ditawarkan oleh e-commerce. E-commerce telah merevolusi perilaku penjual dan konsumen dalam bertransaksi, dimulai dari menawarkan barang, memasarkan hingga bertransaksi. Semua dilakukan tanpa batas waktu dan jarak dan dilakukan tanpa perlu bertatap muka secara langsung. Apalagi saat ini website e-commerce telah banyak ditawarkan, tidak hanya website berbayar melainkan banyak pula yang nonpremium (gratis) sehingga menjadi tidak ada alasan bagi pelaku usaha untuk tidak turut serta dalam berbisnis melalui media e-commerce.

\section{Perencanaan Keuangan Islam sebagai Strategi Pengelolaan Keuangan}

Meskipun perkembangan teknologi telah memberikan kemudahan dalam proses transaksi tetap dibutuhkan adanya perencanaan sebuah usaha. Karena perencanaan merupakan salah satu hal yang penting bagi keberlangsungan suatu usaha. Maka menjadi benar ketika sebuah pepatah mengatakan "Jika Anda gagal merencanakan sesuatu, maka sama artinya dengan Anda merencanakan untuk gagal". Pepatah tersebut menekankan bahwa setiap usaha yang kita lakukan maka rencanakanlah dengan baik. Berbicara tentang perencanaan maka kita terfokus pada pentingnya perencanaan keuangan bagi sebuah usaha baik bersakala kecil atau besar. Mengutip pendapat Bajtelsmit dan Bernasek (Bajtelsmit and Bernasek 1996), perencanaan adalah sebuah proses pengembangan dan penerapan yang terintegrasi secara komprehensif dengan rencana yang dirancang untuk memenuhi kebutuhan keuangan.

Jika Bajtelsmit dan Bernasek telah mendefiniskan perencanaan secara umum, maka dalam ekonomi Islam konsep perencanaan keuangan lebih 
dikenal dengan istilah Islamic financial planning. Implementasi Islamic financial planning merupakan bagian dari manajemen kekayaan Islam atau Islamic wealth management. Jika Al-Ghazali telah mendeskripsikan kesejahteraan dengan terpenuhinya lima kebutuhan dasar manusia, yaitu agama, jiwa, akal harta dan keturunan, maka implementasi Islamic financial planning harus mencakup lima kebutuhan dasar tersebut. Tanpa adanya perencanaan maka menjadi mustahil lima kebutuhan dasar manusia akan terpenuhi sesuai porsinya. Salah satu bentuk implementasi Islamic wealth management yang sangat penting adalah manajemen harta/aset.

Aset dalam PSAK no 16 revisi 2011 didefinisikan semua kekayaan yang dimiliki oleh seseorang atau perusahaan baik berwujud maupun tidak berwujud yang bernilai dan akan mendatangkan manfaat bagi pemiliknya. Jika kepemilikan aset dalam akuntansi bersifat mutlak maka berbeda dengan kepemilikan aset dalam perspektif Islam. Islam menganggap harta atau kekayaan adalah "amanah" yang harus dikelola dengan baik tanpa mengabaikan hak orang lain di dalamnya. Sejalan dengan pendapat yang dikemukakan Nurdin dan Muslina (Nurdin and Muslina 2017) yang menyatakan bahwa harta merupakan kepemilikan sementara yang dititipkan Allah kepada manusia.

Masruroh (Masruroh 2013) menyatakan bahwa pengelolaan keuangan secara syariah dapat menumbuhkan good money habbit. Good money habbit diartikan sebagai sebuah kebiasaan yang baik dalam pengelolaan atau perencanaan keuangan. Ketika kita sudah mengalokasikan dana untuk zakat, kebutuhan primer dan merencanakan kebutuhan masa depan maka dapat dikatakan sebagai good money habbit, sebagaimana firman Allah:

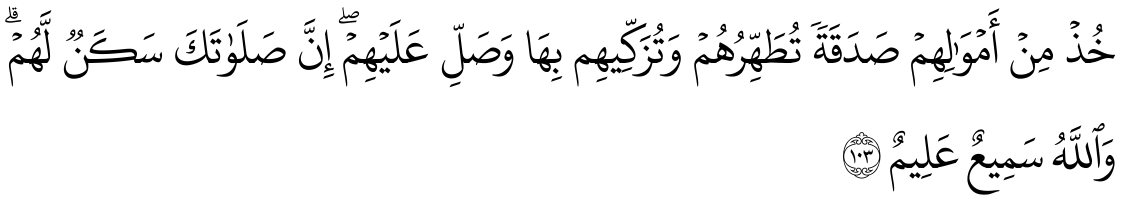

Economica: Jurnal Ekonomi Islam - Volume 9, Nomor 1 (2018) http://journal.walisongo.ac.id/index.php/economica 
Naili Saadah

"Ambillah zakat dari sebagian harta mereka, dengan zakat itu kamu membersihkan dan mensucikan mereka dan mendoalah untuk mereka. Sesungguhnya doa kamu itu (menjadi) ketenteraman jiwa bagi mereka. Dan Allah Maha Mendengar lagi Maha Mengetahui." (QS. Al-Taubah [9]: 103).

Ayat tersebut mempertegas bahwa harta yang dimiliki oleh manusia adalah sebuah "amanah" yang harus dikelola dengan baik. Anjuran untuk menginfakkan harta dan mengeluarkan zakat dikenal dengan konsep istikhläf. Konsep ini digaungkan oleh Yusuf Qardhawi (Qardhawi 1997) menyatakan bahwa harta bukan milik manusia secara mutlak tetapi milik Allah dan manusia hanya sebagai wakil Allah yang wajib memelihara harta yang dimilikinya.

\section{Metode Penelitian}

Penelitian ini berusaha menarik kesimpulan berdasarkan fakta sosial yang ada di masyarakat. Oleh karena itu penelitian ini termasuk dalam kategori penelitian sosial. Neuman (Neuman 2011) memaparkan bahwa penelitian sosial terbagi menjadi dua jenis, yaitu penelitian kualitatif dan kuantitatif. Perbedaan kedua jenis penelitian tersebut terletak pada bagaimana cara pengukuran objek penelitian. Jika dalam penelitian kuantitatif lebih memfokuskan pada pengukuran angka atau melihat hasil penelitian dengan mengukur fakta-fakta objektif maka dalam penelitian kualitatif bertujuan untuk menarik kesimpulan dengan melihat kenyataan sosial atau melalui pembentukan kenyataan sosial.

Sejalan dengan penelitian ini yang tidak berusaha untuk mengukur fakta objektif berdasarkan angka numerik melainkan menarik kesimpulan dari partisipan atau responden tentang kondisi sosial yang terjadi saat ini terkait bagaimana perempuan-perempuan yang aktif berbisnis e-commerce melakukan perencanaan keuangan maka penelitian ini termasuk dalam kategori penelitian kualitatif dengan memfokuskan objek penelitian pada 
kaum perempuan pengguna aktif online shop atau pelaku usaha yang berbasis e-commerce lainya.

Dalam penelitian kualitatif kita mengenal empat paradigma yang telah dipaparkan oleh Burrel dan Morgan sebagaimana dikutip Hidayat (Hidayat 2002). Empat paradigma tersebut terdiri dari radical humanist, radical structuralist, interpretive, dan functionalist. Bukan tanpa maksud Burrel dan Morgan membagi empat paradigma tersebut karena masing-masing paradigma mempunyai karakteristik yang berbeda.

Untuk menjawab permasalahan yang telah dipaparkan sebelumnya maka penelitian ini dirasa lebih tepat menggunakan paradigma interpretive. Merujuk pendapat Ludigdo (Ludigdo 2013) paradigma interpretive atau biasa disebut paradigma konstruktif dilakukan untuk memahami realitas dunia apa adanya. Sejalan dengan penelitian ini yang berusaha memahami fenomena sosial tentang pengelolaan keuangan Islam yang dilakukan pelaku usaha marketplace atau online shop. Maraknya bisnis marketplace atau online shop menjadi fenomena baru dalam dunia bisnis yang menarik untuk dikaji secara natural. Untuk itu paradigma interpretive paling tepat digunakan dalam penelitian ini, karena penelitian ini berusaha mengkaji tentang bagaimana menegelola harta dalam prinsip Islam sesuai dengan keyakinan seorang pelaku usaha muslim.

Paradigma dalam kontek kehidupan diartikan sebagai keyakinan dasar yang menuntun seseorang bertindak dalam kehidupan sehari-harinya (Ludigdo 2013). Sedangkan dalam penelitian, paradigma digunakan menjadi acuan untuk mengungkap fakta. Interpretive dimaknai dengan pengetahuan atau pemikiran umum yang diberikan individu berisikan arti terhadap pengalaman dan kehidupanya sehari-hari (Wahyuni and Nentry 2017). Paradigma interpretive digunakan dalam penelitian ini untuk mendalami pemahaman konsep Islam dalam pengelolaan harta secara sederhana. 
Naili Saadah

Memperkuat paradigma interpretive yang digunakan dalam penelitian maka metode etnografi menjadi pilihan yang tepat untuk digunakan. Etnografi merupakan sebuah metode yang banyak dilakukan untuk memahami perilaku manusia. Neuman (Neuman 2011) menjabarkan definisi etnografi secara etimologi yakni ethno berarti manusia dan graphy berarti menulis. Dengan kata lain, Neuman mendefinikan etnografi sebagai metode penelitian yang dilakukan untuk memahami manusia secara alamiah, atau dengan bahasa aslinya (Neuman 2011). Bukan tanpa sebab etnografi digunakan dalam penelitian ini. Berusaha mendalami keyakinan dan pola pikir seorang pelaku usaha e-commerce tentang pengelolan harta secara alamiah sesuai apa yang diyakini dalam agama, penelitian ini menggunakan dua metode yang berdampingan yaitu studi kasus dan etnografi, Penelitian ini melalui sembilan langkah yang telah dirujukan oleh Spradley dalam penelitiannya (Spradley 2011).

Dimulai dari tahap pertama menentukan informan atau partisipan yang sesuai dengan topik atau tema yang diajukan dalam penelitian ini, peneliti melihat fenomena terkait revolusi industri 4.0 yang sudah dimulai dan terjadi di hampir seluruh dunia termasuk Indonesia. Bisnis e-commerce menjadi sebuah peluang dan tantangan bagi semua pelaku usaha. Di balik perdebatan tentang ancaman bisnis e-commerce ternyata memotivasi kaum perempuan yang kreatif memanfaatkan $e$-commerce sebagai kemudahan tersendiri dalam membuka usaha. Di sinilah muncul pertanyaan bagaimana ibu-ibu yang pada dasarnya tidak memiliki dasar ilmu keuangan merencanakan keuangan bisnisnya.

Berangkat dari latar belakang tersebut maka peneliti tertarik untuk mengetahui lebih lanjut tentang bagaimana perencanaaan keuangan secara syariah yang dilakukan perempuan dalam menjalankan bisnis e-commerce. Dengan meminta salah satu warga di sebuah daerah di Kota Semarang yang aktif menggunakan media e-commerce untuk membuka usaha, peneliti memilih dua partisipan yang memiliki latar belakang yang berbeda. Ibu Amah 
(nama disamarkan untuk kepentingan penelitian) sebagai partisipan pertama karena dia merupakan seorang ibu rumah tangga yang aktif menggunakan media e-commerce untuk berdagang dan juga seorang muslimah. Untuk partisipan kedua peneliti memilih ibu Lina (nama disamarkan untuk kepentingan penelitian), seorang wanita pekerja aktif yang memanfaat peluang bisnis e-commerce sebagai tambahan penghasilannya.

Tahap kedua penelitian ini adalah melakukan wawancara kepada partisipan. Dalam proses interaksi ini peneliti menggunakan bahasa komunikatif yang mudah dipahami partisipan karena partisipan merupakan orang Jawa yang menggunakan bahasa Jawa sebagai bahasa sehari-hari. Sehingga dalam penelitian ini akan ada beberapa kalimat yang menggunakan bahasa Jawa. Penggunaan bahasa Jawa dirasa lebih memperkuat hubungan emosional antara peneliti dengan responden. Hal tersebut sejalan dengan pernyataan Spradley (Spradley 2011), di mana menampakkan bahasa asli partisipan dapat memperkuat suasana kebudayaan partisipan yang sedang diteliti.

Selama proses penelitian peneliti berusaha membaur dengan partisipan dan hadir selama proses penelitian karena kehadiran seorang peneliti dalam penelitian etnografi merupakan aspek penting yang harus ada. Seperti yang dipaparkan (Denzin and Lincoln 2011) bahwa sebuah penelitian kualitatif mensyaratkan peneliti sebagai aktor utama mulai dari perencana, pelaksana, sampai dengan melaporkan hasil penelitian. Akan tetapi peran peneliti di sini hanya sebatas mengobservasi partisipan karena sifat peneliti adalah pasif. Artinya peneliti tidak ikut aktif bertransaksi dengan e-commerce melainkan hanya memerhatikan partisipan dalam bertransaksi online dan menganalisisnya. Namun demikian, adakalanya sesekali peneliti juga terlibat langsung dalam transaksi melalui e-commerce dengan responden melalui pembelian barang dagangan ibu Amah dan ibu Lina yang dijual lewat salah satu marketplace ternama. Menurut Spradley (Spradley 2011) seorang 
Naili Saadah

etnografer harus ikut aktif dalam kegiatan partisipan. Sehingga peneliti dapat memahami perasaan dan kondisi partisipan dalam bertransaksi online.

Pembuatan catatan etnografis menjadi tahap ketiga dalam penelitian ini di mana peneliti mendokumentasikan dengan membuat jurnal harian selama proses pengamatan. Dilanjutkan dengan melakukan wawancara dengan mengajukan pertanyaan deskriptif kepada partisipan sebagai tahap keempat. Tahap kelima, keenam dan ketujuh merupakan tahap analisis data di mana dalam tahap ini peneliti mengelompokkan data-data penting dari hasil pengamatan dan wawancara selam proses penelitian dan menuliskan hasil analisis dalam penjelasan deskriptif. Proses pengamatan dilakukan selama empat bulan mulai dari bulan Januari hingga April 2018. Rentang waktu empat bulan dirasa cukup untuk mengumpulkan data selama proses observasi. Hal ini mengacu kepada pendapat Spradley (Spradley 2011) bahwa masa tiga bulan merupakan rentang waktu paling minimal untuk melakukan penelitian etnografi.

\section{Hasil dan Pembahasan}

\section{Media Sosial sebagai Media Awal Mengenal Bisnis E-Commerce}

Ibu Amah pada mulanya hanya seorang ibu rumah tangga biasa yang setiap harinya hanya bertanggung jawab untuk mengurus keperluan suami dan anak-anaknya mulai pagi hingga malam. Akan tetapi ternyata ketika suami sedang bekerja dan anak-anak sekolah ibu Amah merasa jenuh dan bosan di rumah dengan rutinitas yang monoton setiap harinya. Selain itu, menurut penuturannya bahwa, sebenarnya keinginan untuk bekerja itu ada, karena beliau merasa kebutuhan rumah tangga semakin bertambah akan tetapi tidak bisa meninggalkan anak dan pekerjaan rumah karena masih memiliki anak berusia 4 tahun. Berangkat dari kondisi demikian ide kreatif ibu Amah muncul. Bermodalkan kegemaran beliau yang menyukai seni, ibu Amah menggunakan kreatifitasnya dalam membuat bros atau hiasan jilbab lainnya untuk dijual kepada tetangga dan ditawarkan kepada ibu-ibu ketika bertemu 
di sekolah anaknya. Awalnya ibu Amah hanya membuat bros untuk digunakan sendiri dan anaknya, tetapi beberapa tetangganya ternyata menyukai bros hasil kreatifitasnya dan memintanya untuk dibuatkan bros serupa. Hasil kreatifitas ibu Amah akhirnya banyak diminati. Menurutnya, kreatifitas merupakan bakat yang diwariskan dari leluhur sehingga ketika beliau menekuni pekerjaan yang menjadi keahliannya hasilnya maksimal dan diminati banyak orang.

Dari sana kemudian muncul ide bisnis untuk menekuni usaha ini dan dia mulai menawarkan ke beberapa rekannya. Pada awalnya, ibu Amah terkendala dengan penetapan harga jual produknya, karena mulanya memang tidak berniat untuk memperjualbelikan hasil kreatifitasnya sehingga bahan baku pembuatan produknya tidak diperhitungan dengan biaya-biaya yang menyertainya.

Berbeda dengan partisipan pertama yang memulai bisnis dengan tidak disengaja, Ibu Lina, partisipan kedua memulai bisnis dengan konsep yang telah dipikirkan dengan matang. Karena partisipan kedua ini merupakan wanita pekerja aktif, sehingga dia memilih membuka usaha dengan bergabung menjadi anggota perusahaan kosmetik terkemuka dan aktif menawarkan produknya melalui media online. Selain itu beliau juga bergabung dalam bisnis e-payment, yaitu Paytren.

"Sebenarnya waktu saya itu udah habis di kantor tapi melihat bisnisbisnis online shop saya jadi minat, apalagi berjualan kayak gini nggak harus meluangkan waktu tapi bisa di mana saja, kapan saja. Makanya saya milih jualan oriflame sama ikut paytren-nya Yusuf Mansur aja yang gampang nggak ribet, kalo dua itu kan bisa kepake buat saya juga."

Dari penuturan dua partisipan tersebut peneliti dapat melihat perkembangan financial technology dalam perspektif yang berbeda. Di balik perdebatan tentang peluang dan ancaman revolusi industri 4.0 ternyata mendorong beberapa perempuan kreatif untuk menciptakan sebuah usaha bahkan peluang lapangan kerja yang baru.

Economica: Jurnal Ekonomi Islam - Volume 9, Nomor 1 (2018) 
Naili Saadah

Perlu diketahui bahwa ternyata kedua partisipan sebelum memulai usahanya di bidang e-commerce mereka telah aktif menggunakan media sosial sebagai media awal mengenal bisnis e-commerce. Awalnya kedua partisipan tidak memahami apa sebenarnya bisnis e-commerce. Bahkan ketika awal dilakukan wawancara penelitian pun partisipan belum menyadari kalau ternyata usaha yang mereka tekuni termasuk bisnis e-commerce. Karena sepengetahuan mereka hanya berbisnis secara online, seperti yang dituturkan berikut :

"Jadi awalnya saya itu hanya punya whatsapp. Aplikasi itu pun saya pakai karena untuk mempermudah komunikasi dan mengetahui informasi sekolah anak saya. Kemudian saya diajari anak saya cara mengirim gambar lewat media online. Dari situlah ide bisnis saya untuk berjualan dengan media online muncul." (responden 1, sesi 2)

"Sebelum mulai usaha online ini, saya sudah pernah berjualan lewat hape lewat BBM ya klo dulu. Tapi jaman dulu beda dengan sekarang. Jadi dulu jualan saya nggak laku, terus akhir-akhir ini saya lihat semua orang pake smartphone. Semua jadi bikin saya tertarik lagi jualan online" (responden 2, sesi 3)

Pengakuan kedua responden memberikan fakta menarik bahwa ketika pemerintah mencanangkan cashless society maka sosialisasi tentang teknologi keuangan atau fintech lebih dibutuhkan karena cakupan teknologi keuangan sangat luas dan bentuk implementasi dalam kegiatan bisnis sehari-hari sangatlah beragam.

\section{Talking Accounting sebagai Media Akuntansi}

Berbicara mengenai perencanaan keuangan kita akan terarah kepada ilmu akuntansi, karena sejatinya akuntansi dan perencanaan keuangan merupakan dua hal yang tidak dapat dipisahkan. Akuntansi merupakan bahasa bisnis dalam kegiatan bermuamalah untuk dasar pengambilan keputusan. Sebagaimana pendapat Horngen dan Horrison yang dikutip Setyaningsih (Setyaningsih 2014) bahwa semakin baik seseorang memahami bahasa akuntansi maka semakin baik pula memahami bisnisnya. Maka 
menjadi benar ketika istilah talking accounting yang dikumandangkan oleh Ahrens dalam artikel penelitiannya pada tahun 1997 (Ahrens 1997).

Talking accounting atau membahas akuntansi dengan obrolan ringan menurut Ahrens lebih efektif dibandingkan hanya membaca laporan keuangan, karena dengan melakukan obrolan ringan dengan karyawan atau dengan sejawat akan lebih memahami maksud dan isi dari pencatatan, perencanaan ataupun laporan keungan sehingga tidak salah dalam pengambilan keputusan. Jika sebuah "obrolan ringan" bisa menjadi media yang tepat bagi kelangsungan sebuah bisnis, maka dalam penelitian inipun media tersebut hadir sebagai salah satu media akuntansi untuk pengambilan sebuah keputusan, sebagaimana penuturan partisipan berikut:

"Saya biasanya membicarakan perhitungan dari hasil transaksi jual beli online ketika hari libur. Mengapa saya memilih hari libur, karena saya bisa membicarakan perhitungan dengan situasi yang santai. Terkadang sambil ngobrol kita membicarakan rekap perhitungan. Lebih enak ngobrol dengan anak di situasi yang santai supaya tidak sepaneng."

Dalam penelitian ini implementasi istilah talking accounting diterapkan kedua partisipan pada orang yang dipercaya membantu proses bisnisnya. Jika partisipan pertama memercayakan anaknya untuk membantu usahanya, berbeda dengan partisipan kedua yang menggunakan admin untuk membantu proses bisnisnya.

Penuturan ibu Amah memberikan bukti bahwa untuk membicarakan tentang akuntansi tidak harus dengan suasana yang formal dan serius, karena menurut beliau membicarakan keuangan dengan obrolan santai di waktu senggang dirasa lebih nyaman dan lebih efektif untuk pengambilan keputusan. Jika ibu Amah membutuhkan waktu satu hari dalam seminggu untuk melakukan talking accounting dengan anaknya, berbeda dengan ibu Lina (partisipan kedua) yang memiliki dua admin sebagai karyawan lepas yang membantu usahanya, di mana masing-masing admin mempunyai tugas berbeda. Admin pertama hanya bertugas membantu ibu Lina menjawab 
Naili Saadah

pertanyaan dan pesanan lewat online shop atau marketplace, sedangkan admin kedua bertugas dalam hal transaksi pembayaran.

"Saya setiap hari minta laporan, Mbak, karena saya kan sambil kerja. Jadi nggak bisa ngurusi total. Makanya setiap hari saya minta laporan singkat biar bisa crosscheck sama transferan yang masuk di rekening."

"Laporanya cukup sederhana saja. Yang penting mudah dipahami. Misalnya cukup direkap dalam sehari yang order berapa, yang bayar berapa. Kadang kalau tidak memungkinkan bertatap muka, lewat telepon saja kalau transaksinya sedikit."

Ibu Lina memilih melakukan talking accounting setiap hari walaupun hanya singkat. Berdasarkan penuturan kedua partisipan dalam penelitian ini, dapat disimpulkan bahwa istilah talking accounting yang diungkapkan oleh Ahrens (Ahrens 1997) akan mencapai tujuan ketika masing-masing pihak saling percaya. Kejujuran dalam perkataan inilah yang menjadi kunci kepercayaan. Hal tersebut menguatkan ungkapan Horngen dan Harrison (Horngren and Harrison 2007) bahwa di dalam akuntansi, bisnis ataupun kehidupan kejujuran selalu lebih baik dari kebohongan. Membuktikan bahwa praktik bisnis yang baik adalah praktik bisnis yang etis, sejalan dengan firman Allah:

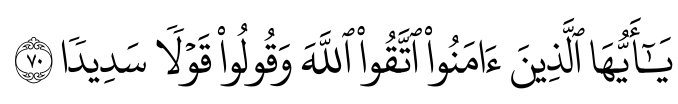

"Hai orang-orang yang beriman, bertakwalah kamu kepada Allah dan katakanlah perkataan yang benar." (QS. al-Ahzab [33]: 70)

\section{Perencanaan Keuangan Islam sebagai Bagian dari Akuntansi Islam}

Paparan sebelumnya menyebutkan bahwa akuntansi merupakan sebuah bahasa dalam berbisnis. Maka sebagai bagian dari rumpun ilmu sosial, akuntansi menjadi sangat dinamis dan rentan terhadap konflik paradigma era kontemporer. Tokoh ekonomi klasik pada waktu itu dianggap sebagai akar dari munculnya pandangan kapitalisme, sebagaimana pemikiran Adam Smith dengan konsep wealth of nation-nya. Sebuah pemikiran yang menyatakan 
bahwa pertukaran dibutuhkan untuk menciptakan kekayaan (Basu, Kirk, and Waymire 2009). Jika dahulu akuntansi sangat erat dengan paradigma ideologi ekonomi kapitalistik yang digaungkan Adam Smith, maka saat ini akuntansi hadir dengan paradigma ideologi yang lebih humanis yaitu akuntansi Islam. Hal tersebut tidak lepas dari hadirnya konsep ekonomi Islam. Sebagai bagian dari turunan ekonomi Islam maka akuntansi Islam sudah seharusnya mencerminkan ideologi dasar Islam yang sesungguhnya. Sebagaimana yang diungkapkan Wahyuni (Wahyuni 2015) bahwa nilai keadilan merupakan nilai dasar dalam ajaran Islam.

Implementasi nilai keadilan sebagai konsep dasar ajaran Islam harus diinternalisasikan ke dalam sebuah sistem yang disebut sistem perencanaan keuangan Islam. Pada prinsipnya tidak ada perbedaan antara perencanaan keuangan Islam dan perencanaan keuangan konvensional, karena definisi perencanaan pada dasarnya merupakan cara bagaimana seseorang mengelola atau mengatur siklus keuangan sehingga biaya yang dikeluarkan tidak melebihi pendapatan yang diterima. Berbicara tentang perencanaan keuangan Islam maka kita akan tertarah pada teori infak yang dicetuskan alShaibani dalam kitab al-Kasb. Meskipun teori infak dianggap sudah terlalu umum akan tetapi sangat tepat untuk dihubungkan dalam manajemen pengelolaan aset. Sebagaimana artikel Ridwan Nurdin dan Muslina (Nurdin and Muslina 2017) yang mengkaji konsep pengelolaan harta merujuk pada konsep khalifah dan keshalihan.

Sesuai dengan teori infak yang dicetuskan al-Shaibani bahwa dalam perencanaan keuangan dalam Islam harus mengeluarkan zakat, infak dan sedekah, sebagaimana yang dilakukan kedua partisipan dalam penelitian ini, "zakat saya hitung juga setiap bulanya. Ya, semua pendapatan dari hasil usaha (jualan) saya itu dasarnya."

Ibu Amah menggunakan pendekatan hasil penjualan sebagai dasar penentuan zakatnya. Konsep perhitungan yang digunakan ibu Amah dinilai relevan untuk digunakan sebagai acuan penghitungan zakat karena 
Naili Saadah

penghitungan zakat berdasarkan omset bukan berdasarkan laba bersih yang ia dapatkan. Jika ibu Amah memasukkan unsur zakat dalam pengelolaan uangnya, maka ibu Lina tidak memasukkan unsur zakat melainkan infak atau sedekah. Menurutnya, "kalo dari yang ini nggak saya zakati soalnya hasilnya naik turun, kadang banyak kadang sedikit, tapi kalo sedekah ya"

Ibu Lina tidak memperhitungkan zakat karena menurutnya usaha onlinenya merupakan bisnis sampingan yang penghasilannya naik turun sehingga tidak wajib dikeluarkan zakat melainkan hanya memasukkan pengeluaran untuk sedekah. Penuturan kedua partisipan menunjukkan bahwa meskipun tidak memasukkan ketiga unsur (zakat, infak, sedekah) secara simultan, tetapi mereka tetap memperhitungkan salah satu aspek pengeluaran yang secara ekonomi tidak menghasilkan keuntungan. Walaupun dapat dikatakan perencanaan keuangan mereka masih sederhana tetapi perencanaan keuangan mereka sudah dapat dikategorikan perencanaan kuangan Islami. Karena tujuan syariah (maqāșid al-sharīah) dari perencanaan keuangan tersebut tercapai. Sebagaimana yang diungkapkan Masruroh (Masruroh 2013) bahwa tujuan dari syariah Islam adalah al-falāh yaitu keberhasilan dalam kehidupan di dunia dan kehidupan di akhirat.

Menetapkan anggaran khusus untuk membayar zakat, infak dan sedekah dianggap sebagai salah satu wujud pemenuhan prinsip dasar ajaran Islam yaitu keadilan sosial. Ibadah manusia dalam aktivitas ekonomi dapat ditandai dengan perbuatan ihsān dan fastabiq al-khairāt serta penegakan al'adl (keadilan) (Latif 2015). Penegakan keadilan di sini terefleksikan dengan pemberian infak dan sedekah sebagai bentuk menciptakan keseimbangan sosial yang merata antara kaya dan miskin, sebagaimana firman Allah:

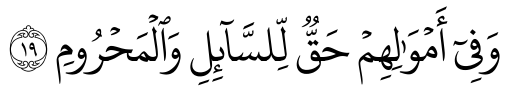

"Dan pada harta-harta mereka ada hak untuk orang miskin yang meminta dan orang miskin yang tidak mendapat bagian." (QS. alDzariyat [51]: 9) 
Perencanaan Keuangan Islam Sederhana...

\section{Simpulan}

Bisnis e-commerce merupakan dunia bisnis yang baru karena merupakan bagian dari revolusi industri 4.0. Di balik digitalisasi proses bisnis e-commerce terselip kearifan pelaku usaha yang tercermin dalam perhitungan perencanaan keuangan Islami. Sebagai makhluk yang memiliki hierarki kebutuhan yang sangat kompleks, manusia dituntut untuk mampu memenuhi konsep good money habbit atau kebiasaan baik dalam membelanjakan uang. Di antaranya memasukan hak orang lain dalam perencanaan keuanganya. Hak orang lain di sini meliputi zakat dan sedekah yang sengaja dianggarkan untuk memenuhi kebutuhan dīn (agamanya). Kesadaran partisipan akan pengeluaran zakat dan sedekah sudah membuktikan bahwa partisipan telah menerapkan konsep good money habbit dalam perencanaan keuangan Islami, karena tujuan dari syariat Islam adalah mendapatkan keberhasilan di dunia dan di akhirat. Bahkan untuk perhitungan besaran zakat dan sedekah yang dikeluarkan, mereka menggunakan patokan omset penjualan bukan laba bersih. Hal tersebut sejalan dengan penelitian Purnomo dan Maulida (Purnomo and Maulida 2017) yang mengelaborasi implementasi financial Islamic planning yang telah dilakukan pengusaha muslim Gontor di mana hasil penelitian membuktikan untuk manajemen filantropi (zakat dan pajak) memperhitungkan secara global sebesar $10 \%$ dari omset untuk zakat infaq dan sedekah. Penggunaan dasar omset penjualan mengindikasikan akan kehati-hatian dalam menetapkan besaran zakat. Kesadaran membayar zakat dan sedekah dianggap sebagai sebuah proses untuk mencapai keberhasilan hidup di akhirat.

Economica: Jurnal Ekonomi Islam - Volume 9, Nomor 1 (2018)

http://journal.walisongo.ac.id/index.php/economica 
Naili Saadah

\section{Daftar Pustaka}

Ahrens, Thomas. 1997. "Talking Accounting: An Ethnography of Management Knowledge In British And German Brewers." Accounting, Organizations and Society 22 (7). Elsevier: 617-37. https://ideas.repec.org/a/eee/ aosoci/v22y1997i7p617-637.html.

Arner, Douglas W., Janos Nathan Barberis, and Ross P. Buckley. 2017. "FinTech, RegTech, and the Reconceptualization of Financial Regulation." Northwestern Journal of International Law \& Business 37 (3): 1-51. https://scholarlycommons.law.northwestern.edu/njilb/ vol37/iss3/2.

Arwani, Agus. 2012. "Epistemologi Hukum Ekonomi Islam (Muamalah)." Religia: Jurnal Ilmu-Ilmu Keislaman 15 (1): 125-46. https://doi.org/https://doi.org/10.28918/religia.v15i1.126.

Bajtelsmit, Vickie L., and Alexandra Bernasek. 1996. "Why Do Women Invest Differently than Men?" Financial Counseling and Planning, 7: 1-10. https://doi.org/10.2139/ssrn.2238.

Basu, Sudipta, Marcus Kirk, and Gregory B. Waymire. 2009. "Memory, Transaction Records, and The Wealth of Nations." Accounting, Organizations and Society 34 (8): 895-917. https://doi.org/10.2139/ ssrn.1008879.

Chapra, Umer. 2001. The Future of Economic: An Islamic Perspective. Jakarta: Shariah Economics and Banking Institute.

Denzin, Norman K, and Yvonna S. Lincoln, eds. 2011. Handbook of Qualitative Research. 3rd ed. California.

Fidiana. 2014. "Eman Dan Iman: Dualisme Kesadaran Dan Kepatuhan." In Simposium Nasional Akuntansi XVII. Mataram: Ekonomi Universitas Mataram.

Hidayat, Dedy. 2002. "Metodologi Penelitian Dalam Sebuah 'Multi-Paradigm Science." Mediator: Jurnal Komunikasi 3 (2): 197-220. https://doi.org/10.29313/MEDIATOR.V3I2.766.

Horngren, Charles T., and Walter T. Harrison. 2007. Akuntansi Jilid 1. 7th ed. Jakarta: Erlangga.

Latif, Abdul. 2015. “Nilai-Nilai Dasar Dalam Membangun Ekonomi Islam.." IAIN Sultan Amai Gorontalo. 
Ludigdo, Unti. 2013. "Asumsi Dasar Paradigma Interpretif." In Accounting Research Training Series Ke-4, 26-27 Juni 2013. Malang: Pascasarjana Akuntansi FEB Universitas Brawijaya.

Masruroh, Aini. 2013. "Mengelola Keuangan Secara Syariah Dalam Rangka Menumbuhkan Good Money Habbit." Al-Iqtishad: Jurnal Ilmu Ekonomi Syariah 5 (1): 79-96. https://doi.org/10.15408/AIQ.V5I1.2557.

Maulana, Shabur Miftah, Heru Susilo, and Riyadi. 2015. "Implementasi ECommerce Sebagai Media Penjualan Online (Studi Kasus Pada Toko Pastbrik Kota Malang)." Jurnal Administrasi Bisnis 29 (1): 1-9. http://administrasibisnis.studentjournal.ub.ac.id/index.php/jab/articl e/view/1165.

McAuley, Daniel. n.d. "What Is FinTech? - Wharton FinTech - Medium." Accessed April 26, 2018. https://medium.com/wharton-fintech/whatis-fintech-77d3d5a3e677.

Neuman, W. Lawrence. 2011. Social Reserach Methods: Qualitative and Quantitative Approachs. 7th ed. Boston: Pearson Publisher.

Nurdin, Ridwan, and Muslina. 2017. "Konsep Dan Teori Manajemen Aset Dalam Islam." Media Syari'ah 19 (2). Fakultas Syariáh IAIN Ar-Raniry: 357-76. https://jurnal.ar-raniry.ac.id/index.php/medsyar/article/ view/2026.

Purnomo, Agus, and Atika Zahra Maulida. 2017. "Implementasi Islamic Financial Planning Dalam Perencanaan Keuangan Pengusaha Muslim Alumni Gontor Yogyakarta." NUANSA: Jurnal Penelitian Ilmu Sosial Dan Keagamaan Islam 14 (1): $103 . \quad$ https://doi.org/10.19105/ nuansa.v14i1.1315.

Qardhawi, Yusuf. 1997. Norma Dan Etika Dalam Ekonomi Islam. 1st ed. Jakarta: Gema Insani Press.

Setyaningsih, Titik. 2014. "Memaknai Kearifan Lokal Pada Perusahaan Keluarga Harta (Sugih Tanpa Bandha) = Utang (Tulung-Tinulung) + Modal (Tuna Satak Bathi Sanak) + Katentreman Ati." In Simposium Nasional Akuntansi XVII. Mataram Nusa Tenggara Barat: Fakultas Ekonomi Universitas Mataram.

Spradley, James P. 2011. The Ethnographic Interview. United States of America: Waveland Press.

"Survei Fintech Indonesia 2016: 61 Persen Startup Fintech Anggap Regulasi Di Indonesia Belum Jelas | Dailysocial." n.d. Accessed June 28, 2018.

Economica: Jurnal Ekonomi Islam - Volume 9, Nomor 1 (2018) 
Naili Saadah

https://dailysocial.id/post/survei-fintech-indonesia-2016-61-persenstartup-fintech-anggap-regulasi-di-indonesia-belum-jelas.

"Tahun 2017 Jumlah Pengguna Internet Di Indonesia Capai 143.26 Juta | Mastel.Id." n.d. Accessed August 20, 2018. http://mastel.id/tahun2017-jumlah-pengguna-internet-di-indonesia-capai-143-26-juta/.

Wahyuni. 2015. "Dekonstruksi Sistem Distribusi Dan Struktur Kepemilikan Usaha Galian Tambang Dalam Bingkai Islam." Universitas Diponegoro Semarang.

Wahyuni, Andi Sri, and Alviana Nentry. 2017. "Ingatan Adalah Media: Studi Etnografi Trik Bertahan Dan Pencatatan Kondisi Keuangan Seorang Paggade-Gadde." Jurnal Akuntansi Dan Bisnis 17 (2): 76. https://doi.org/10.20961/jab.v17i2.227. 